Radiological and chemical toxicity due to ingestion of uranium through drinking water in the environment of Bangalore, India

This content has been downloaded from IOPscience. Please scroll down to see the full text.

2015 J. Radiol. Prot. 35447

(http://iopscience.iop.org/0952-4746/35/2/447)

View the table of contents for this issue, or go to the journal homepage for more

Download details:

IP Address: 14.139.155.11

This content was downloaded on 28/07/2016 at 08:10

Please note that terms and conditions apply. 


\title{
Radiological and chemical toxicity due to ingestion of uranium through drinking water in the environment of Bangalore, India
}

\author{
Gladys Mathews, N Nagaiah, M B Karthik Kumar and \\ M R Ambika
}

Department of Physics, Bangalore University, Bangalore-560056

Karnataka State, India

E-mail: nnagaiah12@rediffmail.com

Received 19 February 2015, revised 24 March 2015

Accepted for publication 10 April 2015

Published 15 May 2015

\begin{abstract}
Groundwater samples collected from 96 bore wells in the study area (city of Bangalore) were analysed for concentration of natural uranium using laserinduced fluorimetry. The risk to the population of the region associated with radiological and chemical toxicity of uranium due to its ingestion through drinking water over a lifetime was estimated. The concentration of uranium was found to be in the range 0.136 to $2027.5 \mu \mathrm{g} \mathrm{L}^{-1}$ with an average value of $92.42 \mu \mathrm{gL}^{-1}$. In the present study, about $61 \%$ of the samples show concentrations of uranium within the safe limit of $30 \mu \mathrm{gL}^{-1}$ as set by the world health organisation. The radiological risk estimated as lifetime cancer risk is in the range $4.3 \times 10^{-7}$ to $6.4 \times 10^{-3}$ with an average of $2.9 \times 10^{-4}$. The chemical toxicity risk measured as lifetime average daily dose is found to range from 0.005 to $75.42 \mu \mathrm{g} \mathrm{kg}^{-1} \mathrm{~d}^{-1}$. The reference dose estimated as $1.12 \mu \mathrm{g} \mathrm{kg}^{-1} \mathrm{~d}^{-1}$ was used to assess the chemical toxicity. The results indicate that the chemical toxicity due to ingestion of uranium through drinking water is of more concern than the radiological toxicity. The present study, being the first of its kind in this region, will augment the database of uranium in groundwater.
\end{abstract}

Keywords: uranium, laser fluorimeter, radiological and chemical toxicity, risk, dose

(Some figures may appear in colour only in the online journal)

\section{Introduction}

Uranium, a long-lived natural radioactive element, is commonly found in rocks, soil, natural materials, food, water and air. It plays an important role in imparting radiation doses to 
members of the public. Uranium enters the human body mainly through inhalation and ingestion. The concentration of uranium in water is typically very small but varies from region to region depending upon the type of minerals in the soil and bedrock. Uranium gets into drinking water when groundwater dissolves minerals that contain uranium. The world health organization (WHO, 2011) has prescribed the safe limit for uranium in drinking water as $30 \mu \mathrm{gL}^{-1}$ [1]. Elevated levels of uranium are more likely to be found in deeper, drilled wells rather than in dug wells or surface water supplies. Studies on this subject have been conducted by various researchers all over the globe. For instance, the concentration of uranium in water samples collected from the Bathinda district of Punjab, India reported by Lakhwant Singh et al [2] was found to be in the range 0.48 to $571.7 \mu \mathrm{g} \mathrm{L}^{-1}$ with a mean value of $84.7 \mu \mathrm{g} \mathrm{L}^{-1}$. The estimated radiological risk due to the ingestion of uranium through drinking water was reported to be in the range $1.34 \times 10^{-6}$ to $1.6 \times 10^{-3}$ with a mean value of $2.37 \times 10^{-4}$, whereas the chemical toxicity was found to be in the range 0.04 to $43.11 \mu \mathrm{g} \mathrm{kg}^{-1} \mathrm{~d}^{-1}$ with a mean value of $6.38 \mu \mathrm{g} \mathrm{kg}^{-1} \mathrm{~d}^{-1}$. The radiological and chemical risk of uranium in groundwater analyzed by Kim et al [3] showed that the excess cancer risks are on the order of $10^{-7}$. The hazard quotient in view of the chemical aspect was found to be 0.005 . Hence, in their study, an adverse health risk due to the ingestion of uranium was found to be unlikely.

\subsection{Health hazards of uranium}

Toxicity due to the ingestion of uranium through drinking water is twofold-radiological toxicity, because the element emits radiations of high ionizing power, and also chemical toxicity due to its being a heavy element [4]. Several studies reveal that the kidney is the most susceptible human organ to the toxic effects of uranium [5,6]. Generally, most uranium in drinking water is eliminated from the body; however, a small amount is absorbed and carried through the bloodstream. Once in the bloodstream, uranium compounds are filtered by the kidneys where they can cause damage to the kidney cells. The chemical effects of uranium in drinking water are of greater concern than the possible effects of radioactivity. In the present study both radiological and chemical toxicity due to the ingestion of uranium through drinking water have been estimated.

\subsection{Study area}

Bangalore is one of the fastest growing cities in Asia and is located in the southeastern part of Karnataka State, India. It covers an area of $2174 \mathrm{~km}^{2}$ with an average elevation of $900 \mathrm{~m}$ above sea level. The soils of the district can be broadly grouped into red loamy and lateritic types. Granites and the peninsular gneissic group constitute the major aquifers in the district [7]. In this region, due to the shortage of treated water, the majority of the population depend on groundwater for their domestic purposes. Since the groundwater is derived from deep granitic and peninsular rocks, it is expected to contain elevated levels of uranium. In recent years, due to rapid and unplanned urbanization and huge growth in population and industrial units, the demand for water has resulted in the indiscriminate drilling of bore wells by individual households, business establishments and industries. This has resulted in depletion of groundwater levels and over-exploitation of the groundwater resources in the district. The deterioration of groundwater quality due to industrial and sewage pollution is the major groundwater problem in this area. Preliminary measurements [8] carried out on the concentration of alpha radioactive nuclides in the groundwater samples show elevated concentrations of uranium and dissolved radon in some locations of the study area. Therefore, to arrive at a robust evaluation of risks to health it was decided to systematically extend the study over a larger area.

The sampling sites in the study area (Bangalore) are shown in figure 1. 


\section{Experimental methods}

Fresh drinking water samples from the bore wells [depth ranges from 90-350 mbgl (metres below ground level)] of the study area were collected from eight study areas, each identified by its compass bearing from Bangalore City railway station. The samples were collected in cleaned and acid washed polythene bottles. All the water samples were filtered through Whatman 42 filter paper. To about of $6 \mathrm{~mL}$ of water sample, $1 \mathrm{~mL}$ of Fluran (sodium pyrophosphate) was added to obtain fluorescence of all uranyl complexes and analyzed for concentration of natural uranium using a pre-calibrated laser-induced fluorimeter. The annual effective dose and the risk associated with radiological and chemical toxicity of uranium due to its ingestion through drinking water was estimated.

\section{Toxicity assessment of uranium}

The toxicity associated with the ingestion of uranium is classified as radiological (carcinogenic) and chemical (noncarcinogenic). In the present investigation, the radiological toxicity estimated as the annual effective dose and lifetime cancer risk due to the ingestion of uranium through drinking water was calculated based on the activity concentration of uranium, the average intake of water and the average life span of the population of the region. The risk arising from the chemical toxicity was estimated in terms of lifetime average daily dose (LADD) and hazard quotient (HQ).

\subsection{Radiological toxicity}

3.1.1. Annual effective dose. The annual effective dose due to the ingestion of uranium through drinking water was calculated as

$$
\boldsymbol{D}=\boldsymbol{A} \cdot \boldsymbol{I} \cdot \boldsymbol{F}
$$

where $\boldsymbol{D}$ is the annual effective dose due to concentration of uranium in water $\left(\mu \mathrm{Svy}^{-1}\right)$, $\boldsymbol{A}$ is the activity concentration of uranium in drinking water $\left(\mathrm{BqL}^{-1} ; 1 \mu \mathrm{g} \mathrm{L}^{-1}\right.$ of uranium is equivalent to $\left.0.02528 \mathrm{~Bq} \mathrm{~L}^{-1}\right), \boldsymbol{I}$ is the annual intake of drinking water $\left(\mathrm{Ly}^{-1}\right)$, equal to $730 \mathrm{Ly}^{-1}$ at the rate of $2 \mathrm{Ld}^{-1}$ [1], and $\boldsymbol{F}$ is the dose conversion factor for natural uranium via ingestion, $4.63 \times 10^{-8} \mathrm{SvBq}^{-1}$ [obtained as the average of the dose coefficients for ${ }^{234} \mathrm{U}$, ${ }^{235} \mathrm{U}$ and ${ }^{238} \mathrm{U}$ isotopes based on international commission for radiological protection (ICRP) publications] [9].

The united nations scientific committee on the effect of atomic radiations (UNSCEAR, 2008) has estimated that the global average for annual effective dose per person from all sources of radiation in the environment is approximately $3.0 \mathrm{mSvy}^{-1}$ out of which $2.4 \mathrm{mSvy}^{-1}$ is due to naturally occurring sources of radiation [10]. An individual dose criterion (IDC) of $100 \mu \mathrm{Svy}^{-1}$ is adopted as a safe limit from the annual consumption of drinking water [1].

3.1.2. Lifetime cancer risk. The lifetime cancer risk was estimated as the product of the risk coefficient and the lifetime effective dose:

Lifetime cancer risk $=$ Risk coefficient $\left(\mathrm{Sv}^{-1}\right) \times$ Lifetime effective dose $(\mathrm{Sv})$, where

Lifetime effective dose $=$ Annual effective dose $\left(\mathrm{Svy}^{-1}\right) \times$ Average lifespan $($ years $)$. 


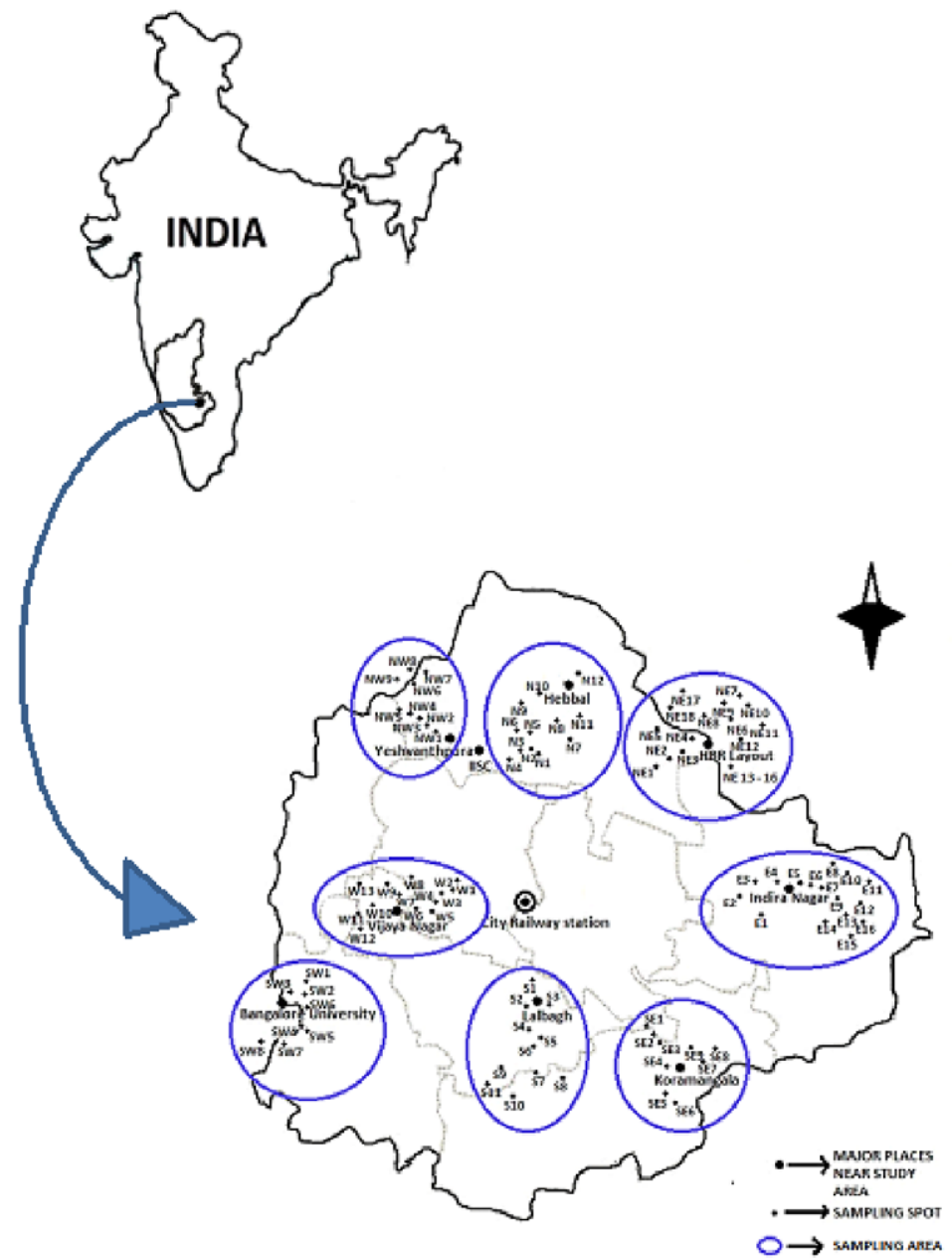

Figure 1. Map showing sampling locations of the study area.

The nominal risk coefficient for radiation-induced cancer incidence is $0.055 \mathrm{~Sv}^{-1}$ (ICRP, 2007) [11]. The acceptable level of radiological risk is $10^{-3}$ [3].

\subsection{Chemical toxicity}

The chemical toxicity risk due to the ingestion of uranium through drinking water was estimated $[12,13]$ in terms of lifetime average daily dose (LADD) using the equation

$$
\operatorname{LADD}\left(\mu \mathrm{g} \mathrm{kg}^{-1} \mathrm{~d}^{-1}\right)=\frac{\mathbf{M C} \times \mathbf{I R} \times \mathbf{E F} \times \mathbf{L E}}{\mathbf{A T} \times \mathbf{B W}}
$$

where

MC = Mass concentration of uranium $\left(\mu \mathrm{gL}^{-1}\right)$,

$\mathbf{I R}=$ Ingestion rate of drinking water $\left(\mathrm{Ld}^{-1}\right)$,

$\mathbf{E F}=$ Exposure frequency (days per year),

$\mathbf{L E}=$ Life expectancy (years), 
AT $=$ Average time $($ days $)=$ Life expectancy $($ years $) \times 365$,

BW $=$ Average body weight of an Indian person $(\mathrm{kg})$.

The ingestion rate of water (IR) was set as $2 \mathrm{Ld}^{-1}[1,14]$ whereas the exposure frequency (EF) was set as $350 \mathrm{~d}$ [14]. The average life expectancy (LE) of an Indian person was taken as 67.8 years [15]. The average time (AT) was $24747 \mathrm{~d}$. The average body weight (BW) of an Indian person was taken as $51.5 \mathrm{~kg}$ [16].

The hazard quotient (HQ) was determined using the relation

$$
\mathrm{HQ}=\frac{\mathbf{L A D D}}{\mathbf{D}_{\boldsymbol{R} f}}=\frac{\mathbf{M C}}{\boldsymbol{C}_{\mathbf{L}}}
$$

where $\boldsymbol{D}_{\mathbf{R f}}$ is the reference dose, equal to $1.12 \mu \mathrm{g} \mathrm{kg}^{-1} \mathrm{~d}^{-1}$ which was calculated on the basis of the average daily consumption of water $(2 \mathrm{~L})$, and $\boldsymbol{C}_{\mathrm{L}}$ is the limiting concentration of uranium in water $\left(30 \mu \mathrm{g} \mathrm{L}^{-1}\right)[1]$.

\section{Results and discussion}

The results obtained in the present study are presented in table1.

\subsection{Radiological risk}

4.1.1. Annual effective dose. The results obtained for uranium concentration in the groundwater samples collected from the study area show that the overall concentration is in the range 0.136 to $2027.5 \mu \mathrm{g} \mathrm{L}^{-1}$ with a mean of $2.42 \mu \mathrm{g} \mathrm{L}^{-1}$. About $22 \%$ of water samples show very high concentrations of uranium $\left(>120 \mu \mathrm{gL}^{-1}\right)$. The observed variation in the concentration can be attributed to the geological features of the study area. The activity concentration of uranium is found to be in the range $3 \mathrm{mBqL}^{-1}$ to $51.26 \mathrm{~Bq} \mathrm{~L}^{-1}$ with a mean of $2.34 \mathrm{BqL}^{-1}$. The results obtained in the present study for the concentration of uranium are comparable with the value reported ( 0.3 to $\left.1442.9 \mu \mathrm{g} \mathrm{L}^{-1}\right)$ in Kolar and Chikkaballapur [17], districts neighboring Bangalore. The number of samples in the various ranges of concentration of uranium in the specified directions of the study area is shown in figure 2 .

The annual effective dose was calculated using equation (1) and is found to be in the range 0.116 to $1732.4 \mu \mathrm{Svy}^{-1}$ with an average of $78.97 \mu \mathrm{Svy}^{-1}$. The safe limit of annual effective dose or individual dose criterion (IDC) from drinking water is $100 \mu \mathrm{Svy}^{-1}$ [1]. In the present investigation, about 20 samples cross this safe limit and 8 samples show an imparted dose greater than $200 \mu \mathrm{Svy}^{-1}$.

4.1.2. Lifetime cancer risk. The radiological risk evaluated as lifetime cancer risk was estimated according to the general ICRP and WHO guidelines. In the present investigation, the overall lifetime cancer risk ranged from $4.3 \times 10^{-7}$ to $6.4 \times 10^{-3}$ with a mean of $2.9 \times 10^{-4}$. Though the average value in all the directions of the study area is low compared to the acceptable limit of $10^{-3}$, the upper end of the range is alarming, which indicates that, with an average intake of water of $2 \mathrm{Ld}^{-1}$ over a lifetime with the present uranium level, about 6 to 7 per thousand people of the most exposed population may suffer from uranium-induced cancer. Specifically, the south region of the study area shows highest value of lifetime cancer risk. In the present study, 6 water samples gave a value of radiological cancer risk higher than the acceptable limit. 


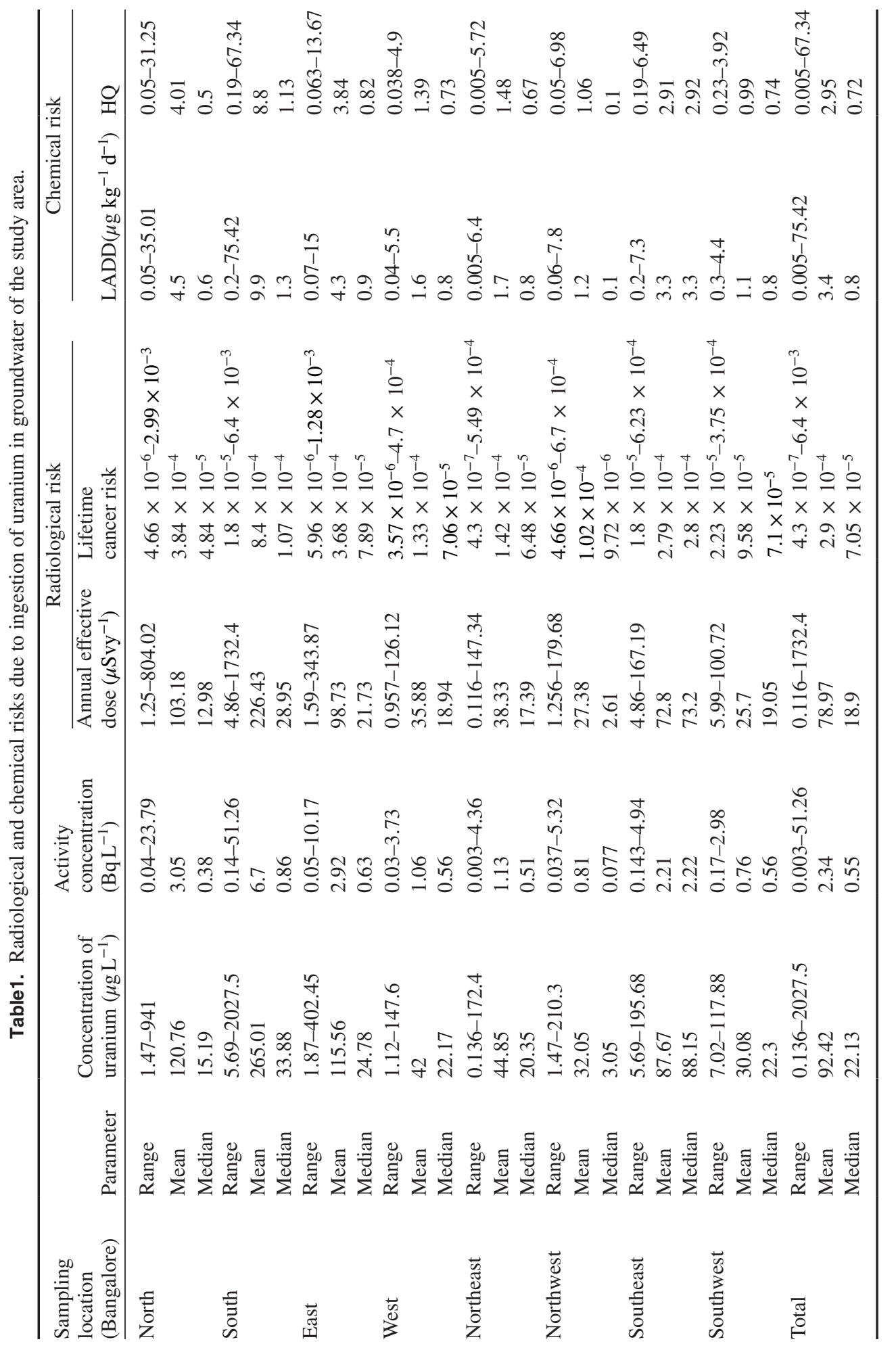




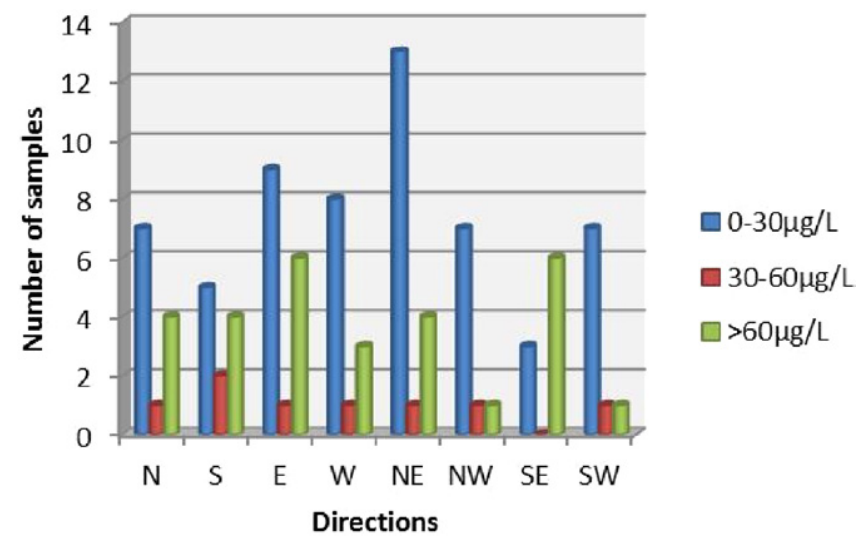

Figure 2. Bar graph showing the number of samples in the various ranges of uranium concentration in the specified directions.

\subsection{Chemical risk}

The risk due to chemical toxicity of uranium was estimated using equations (2) and (3). The estimated LADD is found to be in the range 0.005 to $75.42 \mu \mathrm{g} \mathrm{kg}^{-1} \mathrm{~d}^{-1}$ with a mean of $3.4 \mu \mathrm{g} \mathrm{kg}^{-1} \mathrm{~d}^{-1}$. The reference dose $\left(D_{\mathrm{Rf}}\right)$ was taken as $1.12 \mu \mathrm{g} \mathrm{kg}^{-1}$ based on the average intake of water as $2 \mathrm{Ld}^{-1}$. Out of 96 water samples collected from the bore wells of the study area, 37 samples showed HQ values greater than 1. Looking at the chemical risk direction-wise, the results show all upper limit values to be higher than $D_{\mathrm{Rf}}$. The average value is also found to be higher than $D_{\mathrm{Rf}}$ except in southwest region of the study area. The south region of the study area shows a wide variation in the concentration of uranium and hence the value of $\operatorname{LADD}\left(0.2-75.42 \mu \mathrm{g} \mathrm{kg}^{-1} \mathrm{~d}^{-1}\right)$. The mean value $\left(9.9 \mu \mathrm{g} \mathrm{kg}^{-1} \mathrm{~d}^{-1}\right)$ also varies considerably from the median $\left(1.3 \mu \mathrm{g} \mathrm{kg}^{-1} \mathrm{~d}^{-1}\right)$ indicating that this region requires a more precise study in terms of a larger number of samples. A similar trend of variations is observed in the north and east regions also. The southeast and southwest regions show the values of mean and median equal or nearly equal. A value of $\mathrm{HQ}>1$ indicates that the risk arising out of chemical toxicity of uranium as a heavy element is high.

The result obtained in the present study are compared with the report in an epidemiological study by Kurttio et al [18] which was used to define a no-effect group due to the ingestion of uranium. In their study, the no observed adverse effect level (NOAEL) was estimated as $1094 \mu \mathrm{g} \mathrm{d}^{-1}$ considering the daily intake of water as $2 \mathrm{~L}$, which corresponds to a concentration of $547 \mu \mathrm{gL}^{-1}$ of uranium. Based on that study, and taking into account the difference in intraspecies sensitivity, the WHO has set the tolerable daily intake (TDI) as $60 \mu \mathrm{g}$ [1]. In the present study, the range of concentration of uranium in the water samples of the study area is 0.136 to $2027.5 \mu \mathrm{g} \mathrm{L}^{-1}$. With a daily intake of $2 \mathrm{~L}$ of water of such concentration, ingestion is 0.27 to $4055 \mu \mathrm{g} \mathrm{d}^{-1}$ which is very high compared to the TDI set by WHO and the NOAEL reported by Kurttio et al.

The chemical toxicity estimated as the LADD due to the ingestion of uranium through drinking water along the specified directions of the study area and plotted as a box-andwhisker diagram is presented in figure 3.

\section{Conclusion}

The present investigation on the concentration of uranium in potable groundwater samples and the associated health risk assessment revealed that about $39 \%$ of the groundwater samples 


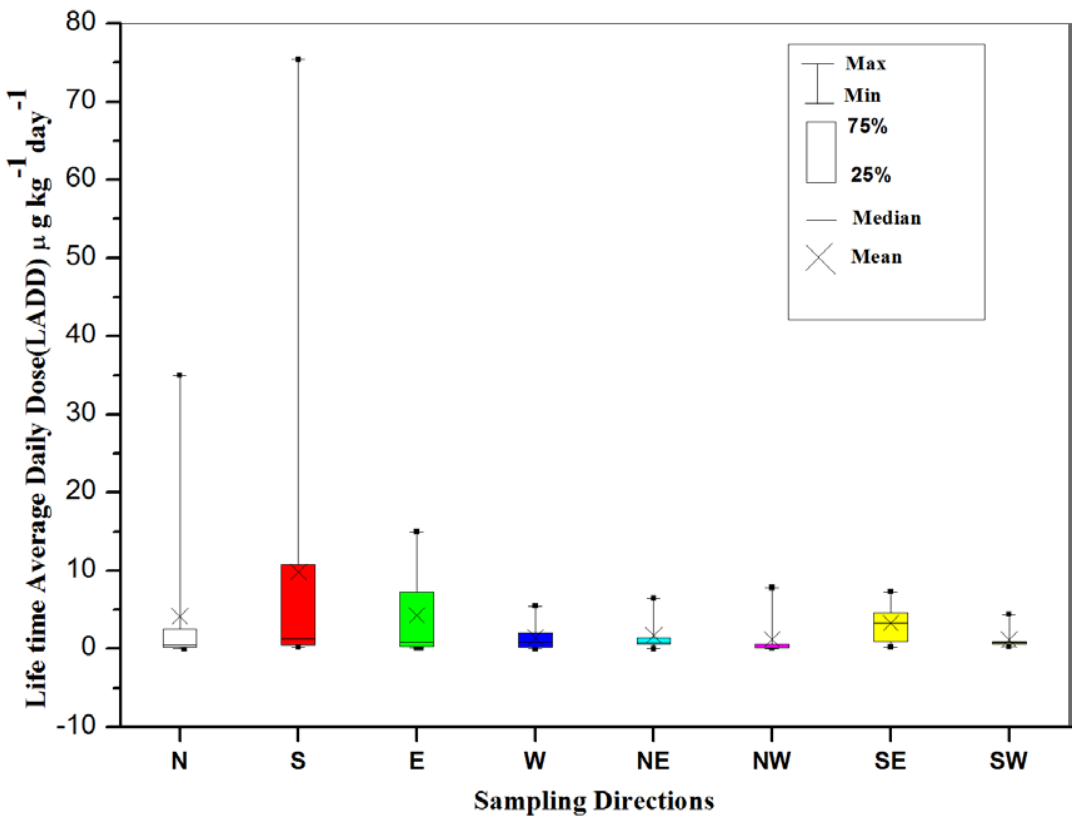

Figure 3. Box-and-whisker plot showing lifetime average daily dose (LADD) in the specified study directions.

show a concentration of uranium higher than the safe limit of $30 \mu \mathrm{g} \mathrm{L}^{-1}$ set by WHO (2011). On comparing the radiological and chemical risks associated with the ingestion of uranium through drinking water, it was found that out of the total number of water samples (96) collected from the study area, about $6 \%$ show values higher than the acceptable level of $10^{-3}$ for radiological risk, whereas $39 \%$ of the samples show risk due to chemical toxicity of uranium. Hence the chemical toxicity of uranium should be of more concern than its radiological toxicity in the area that was surveyed. A more detailed analysis is suggested for the areas where relatively high values of uranium concentration were observed.

\section{Conflict of interest}

There are no conflicts of interest.

\section{Acknowledgments}

The authors express their gratitude to the residents of the study area for their cooperation during the sample collection. One of the authors (Gladys Mathews) also thanks the University Grants Commission (UGC) for granting the permission under the Faculty Development Programme (FDP) to pursue this research work.

\section{References}

[1] World Health Organization 2011 Uranium in drinking water WHO Guidelines for Drinking Water Quality 4th edn (Geneva: World Health Organization) 
[2] Singh L, Kumar R, Kumar S, Bajwa B S and Singh S 2012 Health risk assessments due to uranium contamination of drinking water in Bathinda region, Punjab state, India Radioprotection 48 191-202

[3] Kim Y-S, Park H-S, Kim J-Y, Park S-K, Cho B-W, Sung I-H and Shin D-C 2004 Health risk assessment for uranium in Korean groundwater J. Environ. Radioact. 77 77-85

[4] Hakinson-Hayes A C, Fresquez P R and Whicker F W 2002 Assessing potential risks from exposure to natural uranium in well water J. Environ. Radioact. 59 29-40

[5] Kurttio P, Auvinen A, Salonen L, Saha H, Pekkanen J, Mäkeläinen I, Väisänen S B, Penttilä I M and Komulainen H 2002 Renal effects of uranium in drinking water Environ. Health Perspect. $110337-42$

[6] Zamora M L, Tracy B L, Zielinski J M, Meyerhof D P and Moss M A 1998 Chronic ingestion of uranium in drinking water: a study of kidney bioeffects in humans Toxicol. Sci. 43 68-77

[7] Central Ground Water Board, Government of India 2013 Groundwater Information Booklet (Karnataka: Bangalore Urban District)

[8] Shivaprasad N G 2012 Studies on natural radiation level in the environment of Bangalore, India PhD Thesis submitted to Bangalore University

[9] International Commission on Radiation Protection 2012 Compendium of Dose Coefficients based on ICRP Publication 60 (ICRP Publications119, Annals of the ICRP) vol 41 (Suppl. 1) (Amsterdam: Elsevier)

[10] United Nations Scientific Committee on the effects of atomic radiations 2008 Sources and effects of ionising radiations vol 1 Report to general assembly (New York: United Nations)

[11] International Commission on Radiation Protection 2007 The 2007 Recommendations of the International Commission on Radiological Protection (ICRP Publication103, Annals of the ICRP) vol 37 (Amsterdam: Elsevier)

[12] United States Environmental Protection Agency 2000 Preliminary Health Risk Reduction and Cost Analysis: Revised National Primary Drinking Water Standards for Radionuclides Review Draft (Washington, DC: United States Environmental Protection Agency)

[13] Summary guidelines for Canadian drinking water quality 1999 Prepared by Federal Provincial subcommittee on drinking water of the Federal Provincial Territorial committee on Environmental and occupational health (Ottawa: Canada)

[14] United States Environmental Protection Agency 1999 EPA Standard Default Exposure Factors (Washington, DC: United States Environmental Protection Agency)

[15] Central Intelligence Agency (US): 2014 The World Fact Book (www.cia.gov/library/publications/ resources/the-world-factbook/docs/whatsnew.html)

[16] Dang H S, Jaiswal D D, Parameshwaram M and Krishnamony S 1994 Physiological and Metabolic Data for Reference Indian Man-A proposal (Mumbai: Bhaba Atomic Research Centre)

[17] Sridhar Babu M N, Somashekar R K, Kumar S A, Shivanna K, Krishnamurthy V and Eappen K P 2008 Concentration of uranium levels in groundwater Int. J. Environ. Sci. Technol. 5 263-6

[18] Kurttio P, Harmoinen A, Saha H, Salonen L, Karpas Z, Komulainen H and Auvinen A 2006 Kidney toxicity of ingested uranium from drinking water Am. J. Kidney Dis. 47 976-82 